\title{
PERAN MODERASI PERCEIVED CORPORATE SOCIAL RESPONSIBILITY DALAM PENGARUH TRUST TERHADAP LOYALITAS DAN REPURCHASE INTENTION PADA AIR MINUM DALAM KEMASAN MEREK AQUA DI SURABAYA
}

\author{
Christina Esti Susanti \\ Fakultas Bisnis \\ Unika Widya Mandala Surabaya
}

In recent business competition, marketing managers try to satisfying consumers and building stable-long term relationship between company and consumer. The relationship needs consumer's trust to company. That is why marketing managers are interested in knowing the impact of trust, loyalty and corporate social responsibility (CSR) toward customer retention (repurchase intention) in order to develop the long term profitability of the company. The long term relationship with consumers results in profitability and also impacts of survival and company development. In other word, trust influences toward loyalty and consumer retention. In the same moment, it is not surprising that academicians and practitioner effort to understand trust, customer loyalty, repurchase intention and CSR. This research examines firstly, influence of customer trust toward customer loyalty. Secondly, the research examines influence of customer loyalty toward repurchase intention. Thirdly, the research examines the role of perceived CSR as a moderating variable on the influence customer trust toward customer loyalty.

The packaged-drinking water Aqua is taken as the research context because the Aqua company have donated 10 litter clean water in East Indonesia for each of one litter consumer buying.

The result of the research shows that perceived CSR play a strong and positive role of influencing trust toward loyalty. Otherwise, trust influences strongly toward loyalty and loyalty influences strong enough toward repurchase intention.

The result is expected to give managerial benefit for Aqua Company and also theoretical development in marketing related to the moderation role of perceived CSR in the influence of trust toward loyalty and repurchase intention.

Keywords:

perceived corporate social responsibility, trust, loyal-ty, repurchase intention 


\section{PENDAHULUAN}

CSR merupakan suatu elemen penting dalam kerangka sustainability yang mencakup aspek ekonomi, lingkungan, dan sosial budaya. CSR merupakan proses penting dalam pengelolaan biaya dan keuntungan kegiatan bisnis dengan stakeholders baik secara internal (pekerja dan shareholders) maupun eksternal (kelembagaan pengaturan umum, masyarakat, dan perusahaan lain), dimana tidak hanya terbatas pada konsep pemberian donor saja, namun konsepnya sangat luas dan tidak bersifat statis dan pasif, akan tetapi merupakan hak dan kewajiban yang dimiliki bersama antar stakeholder. Jadi, dalam implementasi CSR, perusahaan tidak hanya mendapatkan keuntungan ekonomi, tetapi juga mendapatkan keuntungan sosial dan lingkungan alam bagi keberlanjutan perusahaan serta mencegah terjadinya konflik.

Menurut Budimanta (2004) konsumen merasakan trust kepada perusahaan jika melihat perusahaan tersebut benar-benar melakukan sesuatu untuk menjadikan dunia suatu tempat yang lebih baik. Hal tersebut membuktikan bahwa sudah saatnya bagi setiap perusahaan untuk memperhatikan CSR sehingga sustainability manusia, ekonomi, sosial, maupun lingkungan dapat terwujud.

Manajemen pemasaran melampaui beberapa era orientasi meliputi era orientasi: produksi, produk, penjualan, pemasaran, pemasaran sosietal, dan sekarang adalah era orientasi pemasaran relasional (Kotler, 1994). Perubahan era tersebut merefleksikan perubahan nilai pelanggan. Oleh karena itu perusahaan harus adaptasi terhadap perubahan nilai pelanggan tersebut dengan membangun relasi jangka panjang dengan konsumen agar tetap bertahan dan berkembang. Telah lama pemasar memberi perhatian terhadap konsep loyalitas. Sebab loyalitas mengukur hubungan antara konsumen dengan perusahaan (Aaker, 1991). Loyalitas memberi banyak manfaat bagi perusahaan seperti repurchase intention, positive word of mouth, hubungan jangka panjang, dan pengembangan yang berkelanjutan. Apabila perusahaan mendapatkan loyalitas konsumen maka sesungguhnya hal tersebut mencerminkan bahwa konsumen memiliki trust kepada perusahaan.

Trust bertalian dengan persepsi konsumen terhadap air minum dalam kemasan Merek Aqua. Trust menjadi faktor penting dalam setiap hubungan dimana trustor tidak dapat mengontrol tindakan trustee (Mayer et al., 1995). Trust merupakan ciri utama dalam interaksi antar manusia terutama ketika hasil interaksi tidak dapat sepenuhnya dikontrol atau dijamin kepastiannya (Thibaut, 1959). Kurangnya trust menjadi alasan yang paling sering dikemukakan konsumen untuk tidak melakukan pembelian ulang (Huang et al., 2007). Bukti empiris menunjukkan bahwa semakin tinggi trust konsumen kepada vendor, semakin tinggi niat konsumen untk melakukan niat beli ulang (Gefen and Straub, 20040) sebagai salah satu indikator loyalitas.

Loyalitas konsumen menunjukkan adanya kecenderungan perilaku untuk terus mengadakan relasi dengan perusahaan. Pada umumnya konsumen menjadi loyal kepada perusahaan karena mendapatkan kepuasan atas produk dan pelayanan perusahaan. Namun menurut Yuen (2007) loyalitas lebih akurat digunakan sebagai hasil dari trust jika dibandingkan sebagai hasil dari kepuasan. Hal tersebut disebabkan oleh karena customer trust mampu mendorong perusahaan untuk senantiasa memuaskan konsumennya. 
Repurchase intention menurut Griffin (1995:31) adalah sebuah intensi konsumen untuk terus menjalin hubungan dengan perusahaan atau penjual. Oleh karena itu pengukuran repurchase intention pada umumnya adalah kecenderungan konsumen untuk membeli merek yang sama, produk atau pelayanan yang sama, dari perusahaan atau penjual yang sama.

Berdasarkan latar belakang dan teori tersebut, rumusan masalah yang diajukan dalam penelitian ini adalah:

a. Apakah trust berpengaruh terhadap loyalitas konsumen pada air minum dalam kemasan Merek Aqua di Surabaya?

b.Apakah loyalitas konsumen berpengaruh terhadap repurchase intention pada air minum dalam kemasan Merek Aqua di Surabaya?

c. Apakah perceived CSR berperan sebagai moderating variable dalam pengaruh trust terhadap loyalitas konsumen pada air minum dalam kemasan Merek Aqua di Surabaya?

Penelitian ini bertujuan menguji kerangka konseptual bahwa perceived CSR merupakan moderasi dari pengaruh customer trust terhadap customer loyalty dalam konteks air minum dalam kemasan Merek Aqua di Surabaya. Selain itu juga menguji pengaruh customer trust terhadap customer loyalty dan repurchase intention.

Berdasarkan tujuan penelitian tersebut, rumusan tujuan dalam penelitian ini disusun sebagai berikut:

a.Pengaruh trust terhadap loyalitas konsumen pada air minum dalam kemasan Merek Aqua di Surabaya.

b.Pengaruh loyalitas konsumen terhadap repurchase intention pada air minum dalam kemasan Merek Aqua di Surabaya.

c. Peran perceived CSR sebagai moderating variable dalam pengaruh trust terhadap loyalitas konsumen pada air minum dalam kemasan Merek Aqua di Surabaya.

\section{TINJAUAN TEORI DAN PENGEMBANGAN HIPOTESIS}

\subsection{Penelitian Terdahulu}

Penelitian terdahulu sehubungan dengan judul yang sama telah dilakukan sebelumnya oleh Yuen (2007). Hasil penelitian tersebut membuktikan bahwa customer trust berpengaruh secara positif dan signifikan terhadap customer loyalty. Perceived CSR berperan sebagai moderating di antara hubungan antara customer trust dengan customer loyalty. Dan customer loyalty berpengaruh positif dan signifikan terhadap repurchase intention.

Sebagaimana dinyatakan oleh Budimanta (2004) bahwa sudah saatnya bagi setiap perusahaan untuk memperhatikan CSR karena banyak manfaat positif yang dapat diperoleh dalam pengaplikasiannya sehingga sustainability (manusia, ekonomi, sosial, maupun lingkungan) dapat terwujud. Oleh karena itu peneliti tertarik mengadakan penelitian sehubungan dengan peran CSR sebagai variebl moderasi dalam pengaruh Trust terhadap Loyalitas di Indonesia. Penelitian yang akan dilakukan ini merupakan replikasi dari penelitian yang telah dilakukan sebelumnya oleh Yuen pada Tahun 2007 dengan perbedaan pada konteks penelitian. Penelitian Yuen dilakukan dengan menggunakan responden dari konsumen apotik di Hongkong. Sedangkan penelitian ini menggunakan konteks konsumen air minum dalam kemasan Merek Aqua di Surabaya.

\section{$2.2 \quad$ Trust}

Trust sudah ada selama sejarah manusia dan sepanjang keberadaan interaksi sosial manusia. Hampir setiap aspek kehidupan manusia didasarkan pada beberapa bentuk trust. Trust merupakan konsep yang mendapat banyak perhatian dari berbagai disiplin ilmu, yaitu: psikologi, 
sosiologi, ekonomi, dan pemasaran (Doney and Cannon, 1997). Akan tetapi, para peneliti berhadapan dengan sulitnya memberikan definisi operasional secara tepat, dan bahkan diantara mereka belum ada kesepakatan mengenai definisi dasarnya (Husted, 1998).

Sebagai sebuah konstruk penelitian yang penting, trust telah banyak diuji dalam berbagai konteks, yaitu: pertukaran sosial, aktivitas bisnis, manajemen, pemasaran, $e$ commerce (Gefen and Straub, 2004). Trust merupakan konstruk yang mengandung beberapa dimensi. McKnight et al., (1998) menyatakan bahwa sebagai sebuah konstruk multidimensi, trust mencakup elemen kognitif (cognitive element) dan niat perilaku (behavioral intention). Sementara itu menurut Lewis and Weigert (1985), trust mencakup elemen kognitif (cognitive element), afektif (affective element), dan niat perilaku (behavioral intention). Aspek niat perilaku berkaitan dengan kecenderungan seseorang untuk berperilaku yang berlatarkan situasi dimana ada dua pihak yang saling tergantung. Sementara itu, aspek kognitif berhubungan dengan keyakinan seseorang terhadap pihak yang dipercaya yang menyediakan peluang untuk terwujudnya perilaku (Lewis and Weigert, 1985). Penelitian membuktikan bahwa aspek kognitif trust berhubungan dengan keyakinan bahwa pihak yang diberi kepercayaan akan berperilaku etis (Hosmer, 1995) dan akan menunjukkan komitmen seperti yang diharapkan oleh pihak yang menaruh kepercayaan dibawah situasi ketergantungan (Rousseau et al., 1998).

Trust kognitif adalah kesediaan konsumen untuk menggantungkan diri pada kemampuan dan keandalan penyedia produk (Moorman et al., 1992; Rempel et al., 1985). Dimensi kognitif mengalir dari kumpulan pengetahuan yang membawa seseorang untuk melakukan prediksi yang berkaitan dengan kemungkinan bahwa partner akan memenuhi kewajibannya. Masih berkaitan dengan aspek kognitif, Geyskens et al., (1996) mendefinisikan trust sebagai pengetahuan (belief) konsumen bahwa ucapan atau janji yang dikatakan oleh penjual dapat diandalkan dan penjual tidak akan mengambil keuntungan dari kelemahan konsumen. Trust kognitif itu dibangun atas dasar pengetahuan konsumen yang diperoleh melalui interaksi. Konsumen memperoleh pengetahuan dengan melakukan penilaian terhadap vendor berkaitan dengan atribut yang dimiliki.

Trust afektif adalah konfidensi konsumen terhadap partner atas dasar perasaan yang muncul karena partner menunjukkan perhatian dan minat (Rempel et al., 1985; Johnson-George and Swap, 1982). Trust afektif ditentukan oleh pengalaman pribadi dengan partner dari pada kognitif trust. Trust afektif dipengaruhi oleh reputasi yang melekat pada partner. Esensi dari trust afektif adalah kepercayaan (reliance) terhadap partner yang didasarkan pada perasaan.

Trust mengandung elemen ketiga selain elemen kognitif dan afektif yaitu niat (intention). Elemen niat menentukan perilaku yang mengalir dari kognisi dan afeksi (Lewis and Weigert, 1985). Intention (niat) didefinisikan sebagai "upaya (effort) yang akan dilakukan seseorang untuk mencapai suatu tujuan", "rencana perilaku (behavioral plan) yang memungkinkan seseorang mencapai tujuan perilaku" Ajzen (1991). Niat dipahami sebagai suatu ukuran tentang kekuatan kemauan seseorang untuk melakukan tindakan tertentu (Fishbein, 1967). Artinya bahwa niat merupakan pernyataan kehendak seseorang untuk mencapai hasil yang diharapkan melalui sebuah proses tertentu yang membutuhkan waktu, pertimbangan, dan perhatian pada hasil tertentu. 
Trust merupakan komponen yang penting untuk kesuksesan aktivitas pemasaran yang dilakukan oleh perusahaan (Lumsden and Mackay, 2006). Quelch and Klein (1996) menyatakan pentingnya peranan trust sebagai faktor yang merangsang niat perilaku belanja. Keen dalam Jarvenpaa et al., (1999) menyatakan bahwa trust merupakan isu jangka panjang dalam mewujudkan repurchase intention. Dikatakan oleh Huang et al., (2007) bahwa trust merupakan komponen penting yang berdampak pada loyalitas dan niat beli ulang. Trust konsumen yang tinggi akan mendorong munculnya loyalitas dan repurchase intention (Gefen and Straub, 2004).

Pada penelitian ini trust diadopsi sebagai antecedence dari loyalitas dan repurchase intention sebab trust merupakan konsep dari intensi untuk secara kontinyu mengadakan hubungan ketika terdapat adanya kepuasan dan ditinjau dari sudut pandang konsumen Surabaya terhadap air minum dalam kemasan Merek Aqua.

Oleh karena itu, hipotesis pertama yang diajukan dalam penelitian ini adalah:

$\mathrm{H}_{1}$ : Trust berpengaruh terhadap loyalitas konsumen pada air minum dalam kemasan Merek Aqua di Surabaya.

\subsection{Repurchase Intention}

Konsep repurchase intention diadopsi dan dimodifikasi dari teori psikologi sosial dan teori pemasaran. Dalam psikologi sosial, repurchase intention adalah sebuah intensi untuk terus menjalin hubungan merujuk pada menjaga hubungan dan saling ketergantungan yang dipayungi oleh teori pertukaran sosial dan teori interdependensi.

Dalam pemasaran, repurchase intention dipelajari dalam area kepuasan pelanggan, loyalitas, dan retensi. Hal tersebut digunakan sebagai indikator dari perilaku pembelian ulang atau retensi pelanggan.

Loyalitas konsumen menunjukkan adanya kecenderungan perilaku untuk terus mengadakan relasi dengan perusahaan. Konsumen menjadi loyal sebab mereka puas dengan perusahaan baik kepada produk yang dihasilkan maupun pelayanan yang diterima maka mereka memiliki kecenderungan untuk mengadakan hubungan di waktu yang akan datang. Dengan kata lain, konsumen yang meninggalkan perusahaan berarti konsumen tidak puas dengan produk maupun pelayanan yang diberikan oleh perusahaan.

Meskipun kepuasan konsumen penting untuk memprediksi loyalitas konsumen, pada masa ini trust dianggap lebih akurat sebagai indikator loyalitas konsumen (Yuen, 2007). Hal tersebut disebabkan oleh karena customer trust memberi keyakinan pada perusahaan untuk menghasilkan produk dan pelayanan yang memuaskan konsumen tidak hanya pada saat ini saja tetapi juga pada masa yang akan datang. Oleh karena itu, pengaruh trust terhadap loyalitas dipercaya lebih besar daripada pengaruhnya terhadap kepuasan sehingga berdampak pada repurchase intention (Yuen, 2007).

Berdasarkan pendapat tersebut, maka dalam penelitian ini trust diteliti pengaruhnya terhadap loyalitas dan pengaruh loyalitas terhadap repurchase intention.

Pengukuran repurchase intention pada umumnya adalah kecenderungan konsumen untuk membeli merek yang sama, produk atau pelayanan yang sama, dari perusahaan atau penjual yang sama.

Pada lingkungan persaingan bisnis masa kini, perusahaan mengelola pelanggan yang dimiliki melalui beberapa program loyalitas. Tujuan program loyalitas tersebut adalah untuk mensukseskan repurchase intention. 
Quelch and Klein (1996) menyatakan pentingnya peranan trust sebagai faktor yang merangsang niat perilaku belanja. Keen dalam Jarvenpaa et al., (1999) menyatakan bahwa trust merupakan isu jangka panjang dalam mewujudkan repurchase intention. Dikatakan oleh Huang et al., (2007) bahwa trust merupakan komponen penting yang berdampak pada loyalitas dan niat beli ulang. Trust konsumen yang tinggi akan mendorong munculnya loyalitas dan repurchase intention (Gefen and Straub, 2004).

Pada penelitian ini trust diadopsi sebagai antecedence dari loyalitas dan repurchase intention sebab trust merupakan konsep dari intensi untuk secara kontinyu mengadakan hubungan ketika terdapat adanya kepuasan.

Penelitian ini bertujuan menggali pengaruh loyalitas dengan repurchase intention.

Berdasarkan landasan teori tersebut, hipotesis yang diajukan dalam penelitian ini adalah:

H2: Loyalitas konsumen berpengaruh terhadap repurchase intention pada air minum dalam kemasan Merek Aqua di Surabaya.

\subsection{Corporate Social Responsibility (CSR)}

Terdapat berbagai definisi tentang CSR, dimana definisi CSR juga semakin berkembang seiring dengan perkembangan dunia global (Budimanta, 2004).

World Business Council for Sustainable Development (WBCSD) in Fox mendefinisikan CSR sebagai komitmen bisnis untuk berkontribusi dalam pembangunan ekonomi berkelanjutan, bekerja dengan para karyawan perusahaan, keluarga karyawan tersebut, masyarakat setempat dan masyarakat secara keseluruhan, dalam rangka meningkatkan kualitas kehidupan. Berdasar pendapat CSR Forum, CSR merupakan bisnis yang dilakukan secara transparan dan terbuka serta berdasarkan pada nilai-nilai moral dan menjunjung tinggi rasa hormat kepada karyawan, komunitas, dan lingkungan.

Jadi, dapat disimpulkan bahwa CSR adalah komitmen perusahaan untuk memberikan kontribusi jangka panjang terhadap satu masalah tertentu di masyarakat atau lingkungan untuk dapat menciptakan lingkungan yang lebih baik. Kontribusi tersebut dapat berupa banyak hal, misalnya: bantuan dana, bantuan tenaga ahli dari perusahaan, bantuan berupa barang, dan lain sebagainya.

CSR dalam pemaknaannya tidak dapat dipisahkan dari maknanya secara filosofis yang terdiri dari ethics, power, recognition, dan governance yang terkait terhadap aspek social, ecology/environment, actor, dan economic. Makna makna filosofis tersebut harus dipandang sebagai satu kesatuan utuh yang tidak dapat dipisahkan baik dari aspek konsep maupun dari aspek pelaksanaannya.

Perusahaan yang menjalankan model bisnisnya dengan berpijak pada prinsipprinsip etika bisnis dan pengelolaan manajemen sumber daya alam yang stratejik dan sustainable akan dapat menumbuhkan citra positif, trust, loyalitas, dan dukungan dari masyarakat. Karena jika perusahaan menjalankan tata kelola bisnisnya dengan baik dan mengikuti peraturan yang telah ditetapkan oleh pemerintah maka pemerintah dan masyarakat akan memberikan trust pada perusahaan tersebut untuk menjalin hubungan dalam jangka panjang.

Melihat pentingnya pelaksanaan CSR dalam membantu perusahaan menciptakan cira positifnya, maka perusahaan seharusnya melihat CSR bukan sebagai pusat biaya namun sebagai pusat laba pada masa mendatang. 
Terdapat berbagai contoh keuntungan pelaksanaan CSR yang dilakukan oleh perusahaan. Contoh-contoh tersebut antara lain (Budimanta, 2004): Di Inggris, sebuah survey membuktikan bahwa 86\% konsumen merasakan trust kepada perusahaan jika melihat perusahaan tersebut benar-benar melakukan sesuatu untuk menjadikan dunia suatu tempat yang lebih baik. Selain itu, di Amerika, Tahun 1999, survey Lembaga Environic menyatakan sepertiga konsumen di Amerika Serikat memiliki trust kepada produk-produk yang dihasilkan oleh perusahaan-perusahaan yang memiliki visi bisnis pembangunan masyarakat yang lebih baik. Sedangkan di Indonesia, data riset Majalah SWA terhadap 45 perusahaan menunjukkan bahwa CSR bermanfaat didalam memelihara dan meningkatkan customer trust kepada perusahaan $(37,38 \%)$, repurchase intention (16,82\%), dan mendukung operasional perusahaan (10,28\%). Hal tersebut membuktikan bahwa sudah saatnya bagi setiap perusahaan untuk memperhatikan CSR karena banyak manfaat positif yang dapat diperoleh dalam pengaplikasiannya. Diharapkan bagi seluruh stakeholder dapat bersama bekerjasama mengembangkan CSR sehingga sustainability (manusia, ekonomi, sosial, maupun lingkungan) dapat terwujud.

Pada penelitian ini CSR yang dimaksudkan adalah CSR yang dilakukan oleh perusahaan penghasil air minum dalam kemasan Merek Aqua dari sudut pandang konsumen, maka disebut dengan perceived CSR.

\subsection{Peran Mediasi Perceived CSR Dalam Pengaruh Trust Terhadap Loyalitas}

Pasar saat ini adalah pasar yang sangat kompetitif. Oleh karena itu, perusahaan dituntut untuk mengelola pangsa pasar yang dimiliki dengan menjaga konsumen yang sekarang dimiliki atau bahkan meningkatkan retensi konsumen dengan program seperti melakukan komunikasi dengan konsumen, memenuhi yang menjadi harapan konsumen, dan menjaga hubungan jangka panjang. CSR menjadi semakin popular adalah sebuah fakta yang secara global diketahui dan seyogyanya dipahami.

CSR merupakan evolusi dari konsep pemasaran. Melalui CSR baik perusahaan maupun pemasar menerima trust dari konsumen untuk menjadi lebih aktif dan rasional. Budimanta (2004) menjelaskan bahwa CSR juga merupakan faktor yang kuat pengaruhnya terhadap trust dan loyalitas konsumen sebab CSR memiliki peran yang unik dalam era konsumerisme masa kini. Namun menurut Yuen (2007) peran CSR sebagai moderating dalam hubungan antara trust dan loyalitas, tidak banyak literatur yang membahas.

Namun dari hasil penelitian yang telah dilakukan di Inggris, Amerika, dan Indonesia oleh Majalah SWA sebagaimana dijelaskan pada poin terdahulu, penelitian ini bertujuan menguji peran CSR sebagai moderating dalam hubungan antara trust dan loyalitas.

Penelitian terdahulu sehubungan dengan judul yang sama telah dilakukan sebelumnya oleh Yuen (2007). Perceived CSR berperan sebagai moderating di antara hubungan antara customer trust dengan customer loyalty. Dan customer loyalty berpengaruh positif dan signifikan terhadap repurchase intention.

Berdasarkan teori dan penelitian terdahulu tersebut, hipotesis yang diajukan dalam penelitian ini adalah:

H3: Perceived CSR berperan sebagai moderating variable dalam pengaruh trust terhadap loyalitas konsumen pada air minum dalam kemasan Merek Aqua di Surabaya. 
Penelitian yang dilakukan ini merupakan replikasi dari penelitian yang telah dilakukan sebelumnya oleh Yuen pada Tahun 2007 dengan perbedaan pada konteks penelitian. Penelitian Yuen dilakukan dengan menggunakan responden dari konsumen apotik di Hongkong. Sedangkan penelitian ini menggunakan konteks konsumen air minum dalam kemasan Merek Aqua di Surabaya.

Berdasarkan tinjauan teori dan hipotesis yang dikembangkan dalam penelitian ini, model riset dibangun sebagai berikut (Gambar 1.):

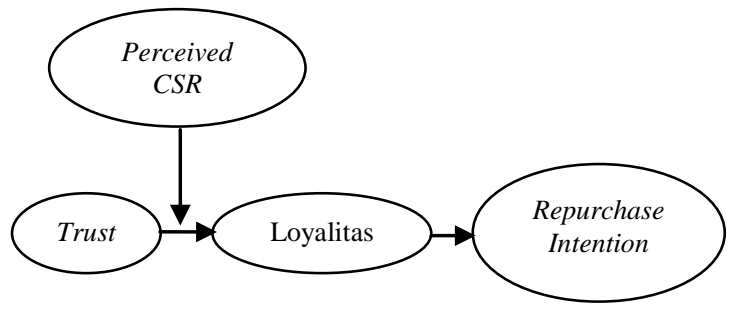

Gambar 1.

Model Riset

\section{METODE RISET}

\subsection{Desain Penelitian}

Pendekatan kuantitatif diterapkan diterapkan dalam penelitian ini dengan alasan melalui pendekatan ini proses penelitian dilakukan secara terstruktur dan menggunakan sampel penelitian dengan jumlah cukup besar yang dianggap mewakili populasi yang diteliti. Sampel yang digunakan dianggap dapat mewakili populasi yang diteliti sehingga hasil yang diperoleh dalam penelitian ini merupakan hasil yang konklusif bagi populasi darimana sampel penelitian diambil (Malhotra, 1993:93).

Penelitian ini dirancang dengan menggunakan hipotesis dan bersifat memberi penjelasan terhadap obyek yang diteliti (explanatory reseach). Dengan demikian, penelitian ini menyajikan penjelasan mengenai hubungan kausal antar variabel yang diteliti melalui pengujian hipotesis (Malhotra, 1993:102).

Sementara itu, data yang dibutuhkan dalam penelitian ini adalah data primer yang diperoleh dengan menggunakan instrumen kuesioner. Skala yang digunakan untuk pengukuran data dalam penelitian ini adalah
Skala Likert interval 1 sampai dengan 5 dari sangat tidak setuju ke sangat setuju (Nazir, 1998:397).

Unit analisis dalam penelitian ini adalah konsumen air minum dalam kemasan Merek Aqua di Surabaya. Dimensi waktu penelitian adalah cross sectional, yaitu penelitian dilangsungkan dalam waktu tertentu dengan menggunakan banyak responden (Malhotra, 1993:97).

Penelitian ini bertujuan untuk secara empirik membuktikan: 1) pengaruh trust terhadap loyalitas, 2) pengaruh loyalitas terhadap repurchase intention, dan 3) peran perceived CSR sebagai moderating dalam pengaruh trust terhadap loyalitas. Untuk membuktikan pengaruh variabel-variabel yang diteliti tersebut, dalam penelitian ini digunakan Partial Least Square Analysis (PLS).

\subsection{Identifikasi Variabel}

Variabel-variabel yang digunakan dalam penelitian meliputi variabel independen, variabel moderating, dan variabel dependen. Lebih lengkapnya adalah sebagai berikut:

a. Variabel independen (X): Trust 
b. Variabel moderating (Z): Perceived CSR

c. Variabel dependen $\left(\mathrm{Y}_{1}\right)$ : Loyalitas

d.Variabel dependen $\left(\mathrm{Y}_{2}\right)$ : Repurchase intention

\subsection{Definisi Operasional Variabel}

Variabel-variabel yang digunakan

dalam penelitian ini secara operasional didefinisikan sebagai berikut:

a. Variabel Eksogen: Trust (X)

Kepercayaan konsumen baik kepada perusahaan penghasil maupun kepada produk air minum dalam kemasan Merek Aqua. Menurut Gefen dan Straub (2004) variabel trust diukur dengan:

- Percaya pada keputusan.

- Percaya pada produsen Aqua.

- Percaya perusahaan konsisten.

- Percaya terhadap keamanan kemasan Aqua.

- Yakin kepada produsen Aqua.

b. Variabel Intervening: Loyalitas $\left(\mathrm{Y}_{1}\right)$

Loyalitas konsumen menunjukkan adanya kecenderungan perilaku untuk terus mengadakan relasi dengan perusahaan dengan membeli air minum dalam kemasan Merek Aqua. Dalam penelitian ini, pengukuran variable loyalitas mengikuti pengukuran menurut Griffin (1995:30) dimana variabel ini diukur dengan:

- Terus menjalin hubungan dengan produsen Aqua di masa mendatang.

- Terus mengkonsumsi Aqua pada masa mendatang.

- Terus mengkonsumsi Aqua pada masa mendatang meskipun perusahaan lain menawarkan produk yang sama dengan harga yang lebih murah.

- Bersedia menjadi anggota apabila perusahaan mengada-kan perkumpulan.

- Merekomendasikan kepada orang lain.

- Menyanggah apabila orang lain mengatakan hal-hal negatif tentang Aqua.

\section{c. Repurchase intention $\left(\mathrm{Y}_{2}\right)$} Intensi untuk terus menjalin hubungan sebagai indikator dari perilaku pembelian ulang atau retensi pelanggan. Dalam penelitian ini, pengukuran variable loyalitas mengikuti pengukuran menurut Griffin (1995:31) dimana variabel ini diukur dengan:

- Terus mengkonsumsi Aqua sebab percaya kepada produsen penghasilnya.

- Mengajak anggota keluarga dan teman yang lain terus mengkonsumsi Aqua sebab percaya kepada produsen penghasilnya.

- Bersedia terus mengkonsumsi Aqua meskipun harganya lebih mahal jika dibandingkan dengan merek lain.

d.Perceived CSR (Z)

Komitmen perusahaan untuk berkontribusi dalam pembangunan ekonomi dan manusia secara berkelanjutan dalam rangka meningkatkan kualitas kehidupan. Variabel ini diukur dengan:

- Produsen Aqua membangun citra positif di masyarakat melalui CSR.

- Produsen Aqua tidak semata-mata mencari keuntungan di dalam menjalankan bisnis.

- Konsumen turut membangun aspek ekonomi dan manusia secara berkelanjutan melalui keputusannya mengkonsumsi Aqua.

\subsection{Validitas dan Reliabilitas Alat Ukur}

Uji coba instrumen penelitian dilakukan untuk mendapatkan kepastian bahwa instrumen penelitian ini mengukur apa yang seharusnya diukur (valid) serta mengukur keakuratan dan konsistensi instrumen (reliable). Uji coba ini perlu ditempuh untuk menghindari kesalahan pengukuran pada saat disampaikan kepada responden yang sesungguhnya. 
Uji validitas dalam penelitian ini dilakukan dengan mengukur korelasi antara skor indikator reflektif dengan skor variabel latennya. Untuk tujuan ini loading 0.5 sampai 0.6 dianggap cukup (Ghozali, 2008: 24; Solimun, 2008:78). Item pernyataan dapat dikatakan valid jika memiliki loading $\geq 0.5$.

Uji reliabilitas dalam penelitian ini dilakukan dengan mengukur korelasi antar jawaban pernyataan dalam kelompok indikator. walaupun bukan merupakan standar absolut, kelompok indikator yang mengukur sebuah variabel memiliki reliabilitas komposit yang baik jika mempunyai composite reliability $\geq 0.6$ (Solimun, 2008:79). Dengan kata lain item pernyataan dapat dikatakan reliabel jika memiliki composite reliability $\geq 0.6$.

\subsection{Populasi, Sampel, dan Teknik Pengambilan Sampel}

Populasi dalam penelitian ini adalah konsumen air minum dalam kemasan Merek Aqua di Surabaya. Oleh karena itu karakteristik populasi dapat dinyatakan sebagai berikut:

a. Konsumen air minum dalam kemasan Merek Aqua.

b.Berdomisili di Surabaya.

c. Berusia $\geq 17$ tahun. Penentuan batas usia ini merefleksikan usia dewasa yang sudah dapat memahami kuesioner.

d.Minimal dalam satu hari melakukan konsumsi atas air minum dalam kemasan Merek Aqua sebanyak 1 kali. Frekuensi konsumsi minimal 1 hari 1 kali menjadi dasar asumsi bahwa konsumen sudah familiar dengan air minum dalam kemasan Merek Aqua.

Menurut Babbie (1986:176) sampel merupakan bagian khusus dari populasi yang diteliti. Semakin homogen populasi yang diteliti, semakin kecil besar sampel yang dibutuhkan. Sebaliknya semakin heterogen populasi yang diteliti, semakin besar ukuran sampel yang dibutuhkan. Menurut Nazir (1988:328) sampel adalah kumpulan dari unit sampling, yaitu unit yang membentuk basis dari proses sampling.

Mengingat bahwa dalam penelitian ini digunakan analisis $P L S$, maka besar sampel mengikuti aturan yang ada di dalam PLS. Adapun jumlah sampel ditentukan sebesar 100 sampel.

Teknik pengambilan sample dalam penelitian ini dilakukan dengan nonrandom sampling technique, yaitu teknik pengambilan sampel yang tidak memberi peluang yang sama bagi setiap unsur atau anggota populasi untuk dipilih menjadi sampel. Keterwakilan populasi oleh sampel merupakan syarat yang penting untuk melakukan inferensi atau generalisasi. Oleh karena itu, penentuan sampel dengan menggunakan nonrandom sampling technique, mempertimbangkan jumlah wilayah Surabaya. Kota Surabaya terdiri dari lima bagian wilayah, yaitu: Surabaya Pusat, Surabaya Barat, Surabaya Timur, Surabaya Utara, dan Surabaya Selatan. Distribusi sampel dilakukan secara proporsional. Karena penelitian membutuhkan 100 data responden, maka pada setiap wilayah dalam kota Surabaya akan didistribusikan sejumlah 20 kuesioner dengan pertimbangan proporsional sampel untuk masing-masing wilayah.

\subsection{Teknik Analisis Data \\ 3.6.1 Langkah Pertama}

Teknik analisis data yang digunakan untuk menguji pengaruh Trust, Loyalitas, dan Repurchase Intention adalah Hierarchical Regression, yaitu analisis regresi yang dilakukan secara berjenjang dengan komposisi variabel yang berbeda, mungkin ditambah atau dikurangi. Tujuannya adalah untuk mengetahui perbedaan tingkat pengaruhnya di setiap 
langkah pengujian. Hierarchical regression yang digunakan adalah dengan analisis jalur. Menurut Gozali (2005:15), pada dasarnya analisis jalur merupakan gabungan beberapa analisis regresi linier. Fungsi analisis jalur adalah untuk memediasi hubungan antara variabel bebas dengan variabel terikat yaitu dengan cara melihat pengaruh langsung dan pengaruh tidak langsungnya. Bedanya pada analisis regresi linier, koefisien regresi yang diperhatikan pada analisis jalur adalah nilai standardized beta $(\beta)$.

Selanjutnya melakukan analisis regresi linier (berganda dan sederhana) terhadap masing-masing variabel terikat dengan menggunakan metode enter dengan menggunakan program SPSS versi 13 for windows.

\subsubsection{Langkah Kedua}

Analisis dalam penelitian ini menggunakan regresi moderating interaksi.

$$
\begin{aligned}
& \begin{array}{l}
\text { Persamaan } \\
\text { 2001:150): }
\end{array} \\
& \begin{array}{cl}
\mathrm{Y}=\beta_{0}+\beta_{1} \mathrm{X}_{1} & +\beta_{2} \mathrm{X}_{2}+\beta_{3} \mathrm{X}_{1} \mathrm{X}_{2}+\mathrm{e} \ldots \ldots \ldots . . \\
\text { di mana : } & \\
\mathrm{X} & =\text { Trust } \\
\mathrm{Y}_{1} & =\text { Loyalitas } \\
\mathrm{Z} & =\text { Perceived CSR } \\
\beta_{0} & =\text { Konstanta } \\
\beta_{1}-\beta_{3} & =\text { Koefisien regresi } \\
\mathrm{e} & =\text { variabel pengganggu }
\end{array}
\end{aligned}
$$

\section{ANALISIS DAN PEMBAHASAN}

\subsection{Karakteristik Responden}

Berdasarkan usia, terdapat sebanyak 100 responden yang berusia $\geq 17$ tahun. Hal ini berarti bahwa seluruh responden telah memenuhi karakteristik populasi yang telah ditentukan dalam penelitian ini, sebagaimana terlihat pada Tabel 1.

Tabel 1.

Jumlah Responden Berdasarkan Usia

\begin{tabular}{|c||c||c|}
\hline \hline Usia & $\begin{array}{c}\text { Jumlah } \\
\text { Responden }\end{array}$ & Persentase (\%) \\
\hline \hline$<17$ th & 0 & 0 \\
\hline$\geq 17$ th & 100 & 100 \\
\hline
\end{tabular}

\subsection{Karakteristik Responden \\ Berdasarkan Domisili \\ Berdasarkan domisilinya terdapat} sebanyak 100 responden yang berdomisili di Surabaya. Hal ini berarti bahwa seluruh responden telah memenuhi karakteristik populasi yang telah ditentukan dalam penelitian ini, sebagaimana terlihat pada Tabel 2.

Tabel 2.

Jumlah Responden Berdasarkan Domisili

\begin{tabular}{||l|c||c|}
\hline \multicolumn{1}{|c|}{ Domisili } & $\begin{array}{c}\text { Jumlah } \\
\text { Responden }\end{array}$ & Persentase (\%) \\
\hline \hline Surabaya & 100 & 100 \\
\hline \hline $\begin{array}{l}\text { Luar } \\
\text { Surabaya }\end{array}$ & 0 & 0 \\
\hline
\end{tabular}


4.3

$\begin{array}{lrr}\begin{array}{l}\text { Karakteristik } \\ \text { Berdasarkan } \\ \text { Konsumen }\end{array} & \text { Status } & \text { Responden } \\ \text { Berdasarkan } & \text { statusnya, } & \text { terdapat }\end{array}$

sebanyak 100 responden sebagai konsumen
AMDK merek Aqua. Hal ini berarti bahwa seluruh responden telah memenuhi karakteristik populasi yang telah ditentukan dalam penelitian ini, sebagaimana terlihat pada Tabel 3.

Tabel 3.

Jumlah Responden Berdasarkan Status Sebagai Konsumen

\begin{tabular}{||l||c||c||}
\hline \multicolumn{1}{|c||}{ Status } & $\begin{array}{c}\text { Jumlah } \\
\text { Responden }\end{array}$ & Persentase (\%) \\
\hline \hline Konsumen & 100 & 100 \\
\hline \hline $\begin{array}{l}\text { Bukan } \\
\text { konsumen }\end{array}$ & 0 & 0 \\
\hline \hline
\end{tabular}

\subsection{Karakteristik Responden}

Berdasarkan Pola Konsumsi

Berdasarkan pola konsumsinya, terdapat sebanyak 100 responden yang mengkonsumsi AMDK merek Aqua minimal
1 kali dalam 1 hari. Hal ini berarti bahwa seluruh responden telah memenuhi karakteristik populasi yang telah ditentukan dalam penelitian ini, sebagaimana terlihat pada Tabel4.

Tabel 4.

Jumlah Responden Berdasarkan Pola Konsumsi

\begin{tabular}{|c|c|c|}
\hline Pola Konsumsi & Jumlah & Persentase (\%) \\
\hline 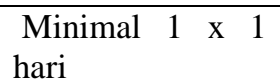 & 100 & 100 \\
\hline Kadang-kadang & 0 & 0 \\
\hline
\end{tabular}

\subsection{Temuan Penelitian}

\subsubsection{Langkah Pertama}

Langkah pertama menjelaskan pengaruh variabel Trust terhadap Loyalitas kemudian pengaruh variabel Loyalitas terhadap Repurchase Intention dengan membuat persamaan garis regresi linier sederhana. Hasil regresi linier sederhana disajikan secara lengkap pada Tabel 5. sebagai berikut.

Tabel 5.

Hasil Penghitungan Regresi Linier Sederhana

\begin{tabular}{|l||c||c||c||c||c||}
\hline \multicolumn{1}{|c|}{ Variabel } & Parameter & B & t $_{\text {hitung }}$ & Sig. & r \\
\hline \hline Konstanta & $\mathrm{b}_{0}$ & 5,345 & 3,015 & 0,003 & - \\
\hline \hline X (Trust) & $\mathrm{b}_{1}$ & 0,425 & 7,324 & 0,000 & 0,518 \\
\hline \hline $\mathbf{Y}_{\mathbf{1}}$ (Loyalitas) & $\mathrm{b}_{2}$ & 0,259 & 4,450 & 0,000 & 0,346 \\
\hline \hline Variabel Terikat & Repurchase Intention & & \\
\hline
\end{tabular}

Berdasarkan Tabel 5. diperoleh nilai konstanta sebesar 5,345, nilai koefisien 
regresi variabel Trust sebesar 0,425 , nilai koefisien regresi Loyalitas sebesar 0,259, sehingga menghasilkan persamaan regresi sebagai berikut:

$$
\mathrm{Y}=5,345+0,425 \mathrm{X}+0,259 \mathrm{Y}_{1}
$$

Bilangan konstan $\left(\mathrm{b}_{0}\right)$ sebesar 5,345 menunjukkan apabila variabel bebas tersebut nilainya sama dengan nol, maka diprediksikan Repurchase Intention sebesar 5,345. Koefisien regresi Trust $\left(\mathrm{b}_{1}\right)$ menunjukkan bahwa Trust mempunyai pengaruh yang positif terhadap Repurchase Intention. Apabila Trust meningkat sebesar satu nilai, sedangkan nilai variabel bebas yang lain konstan, maka Repurchase Intention akan meningkat sebesar 0,425. Koefisien regresi Loyalitas $\left(b_{2}\right)$ menunjukkan bahwa Loyalitas mempunyai pengaruh yang positif terhadap Repurchase Intention. Apabila Loyalitas meningkat sebesar satu nilai, sedangkan nilai variabel bebas yang lain konstan, maka Repurchase Intention akan meningkat sebesar 0,259.

\subsubsection{Langkah Kedua}

Hasil pengolahan data Trust, Perceived CSR dan Loyalitas terlihat pada Tabel 6.

Tabel 6.

Analisis Regresi ModeratingTrust, Perceived CSR, dan Loyalitas

\begin{tabular}{|l||c|c|c|c|c|}
\hline \multicolumn{1}{|c||}{ Variabel } & Parameter & B & t $_{\text {hitung }}$ & Sig. & r \\
\hline \hline Konstanta & $\mathrm{b}_{0}$ & 5,345 & 3,015 & 0,003 & \\
\hline \hline $\begin{array}{l}\text { Interaksi (Trust, } \\
\text { Perceived CSR) }\end{array}$ & $\mathrm{b}_{3}$ & 0,481 & 3,622 & 0,000 & 0,250 \\
\hline \hline Variabel Terikat & Loyalitas & & & & \\
\hline
\end{tabular}

Berdasarkan Tabel 6. diperoleh nilai koefisien regresi interaksi sebesar 0,481. Koefisien regresi interaksi menunjukkan bahwa dengan adanya perceived CSR pengaruh antara Trust dengan Loyalitas yang positif. Apabila nilai interaksi meningkat sebesar satu nilai, sedangkan nilai variabel bebas konstan, maka Loyalitas akan meningkat sebesar 0,481.

\subsection{Pembahasan}

\subsubsection{Trust Berpengaruh Terhadap} Loyalitas Konsumen Pada Air Minum Dalam Kemasan Merek Aqua di Surabaya

Hasil analisis regresi $(\mathrm{Y}=5,345+$

0,425 X) menunjukkan bahwa terdapat pengaruh positif antara Trust terhadap loyalitas konsumen pada air minum dalam kemasan Merek Aqua di Surabaya.

Sedangkan dari hasil uji $t$ menunjukkan bahwa pengaruh Trust terhadap loyalitas konsumen pada air minum dalam kemasan Merek Aqua di Surabaya adalah kuat $(\mathrm{r}=0,518)$ dan signifikan $(\mathrm{t}$ hitung = 7,324).

Koefisien determinasi $\left(r^{2}\right)$ sebesar 0,268 yang berarti bahwa pengaruh Trust terhadap loyalitas konsumen pada air minum dalam kemasan Merek Aqua di Surabaya sebesar 26,8\%. Sedangkan sebesar 73,2\% dipengaruhi oleh variabel independen lain yang tidak diteliti dalam penelitian ini.

\subsubsection{Loyalitas Konsumen Berpengaruh Terhadap Repurchase Intention Pada Air Minum Dalam Kemasan Merek Aqua di Surabaya \\ Hasil analisis regresi $(\mathrm{Y}=5,345+$ 0,259 Y1) menunjukkan bahwa terdapat pengaruh positif antara Loyalitas terhadap Repurchase Intention konsumen pada air minum dalam kemasan Merek Aqua di Surabaya.}


Sedangkan dari hasil uji $t$ menunjukkan bahwa pengaruh loyalitas terhadap Repurchase Intention konsumen pada air minum dalam kemasan Merek Aqua di Surabaya adalah cukup kuat $(r=0,346)$ dan signifikan (t hitung $=4,450$ ).

Koefisien determinasi $\left(r^{2}\right)$ sebesar 0,119 yang berarti bahwa pengaruh Loyalitas terhadap Repurchase Intention konsumen pada air minum dalam kemasan Merek Aqua di Surabaya sebesar 11,9\%. Sedangkan sebesar $88,1 \%$ dipengaruhi oleh variabel independen lain yang tidak diteliti dalam penelitian ini.

\subsubsection{Perceived CSR Berperan Sebagai Moderating Dalam Pengaruh Trust Terhadap Loyalitas Konsumen Pada Air Minum Dalam Kemasan Merek Aqua di Surabaya}

Berdasarkan Tabel 6 diperoleh nilai konstanta sebesar 5,345 dan nilai koefisien regresi interaksi sebesar 0,481 , sehingga menghasilkan persamaan regresi sebagai berikut:

$$
\mathrm{Y}=5,345+0,481 \mathrm{XY}_{1}
$$

Bilangan konstan $\left(\mathrm{b}_{0}\right)$ sebesar 5,345 menunjukkan apabila variabel bebas tersebut nilainya sama dengan nol, maka diprediksikan loyalitas sebesar 5,345. Koefisien regresi interaksi menunjukkan bahwa peran perceived CSR mempunyai peran yang memperkuat pengaruh yang positif antara trust terhadap loyalitas. Artinya apabila interaksi meningkat sebesar satu nilai, sedangkan nilai variabel bebas yang lain konstan, maka loyalitas akan meningkat sebesar 0,481.

\section{KESIMPULAN}

Dari pembahasan yang telah diutarakan pada bagian terdahulu, simpulan yang dapat diambil dari penelitian ini adalah:
- Trust berpengaruh terhadap loyalitas konsumen pada air minum dalam kemasan Merek Aqua di Surabaya. Oleh karena itu, hipotesis 1 yang diajukan dalam penelitian ini diterima dan pengaruh tersebut adalah positif dan signifikan.

- Loyalitas konsumen berpengaruh terhadap repurchase intention pada air minum dalam kemasan Merek Aqua di Surabaya. Oleh karena itu hipotesis 2 yang diajukan dalam penelitian ini diterima dan pengaruh tersebut adalah positif dan signifikan.

- Perceived CSR mempunyai peran moderasi dalam berpengaruhnya Trust terhadap loyalitas konsumen pada air minum dalam kemasan Merek Aqua di Surabaya. Oleh karena itu, hipotesis 3 yang diajukan dalam penelitian ini diterima dan peran tersebut positif dan signifikan.

\section{IMPLIKASI MANAJERIAL}

Berdasarkan hasil temuan penelitian, implikasi manajerial yang disampaikan adalah:

- Hasil penelitian membuktikan bahwa repurchase intention pada air minum dalam kemasan Merek Aqua di Surabaya dipengaruhi secara kuat, positif, dan signifikan baik oleh variabel Trust maupun oleh variabel loyalitas. Oleh karena itu seyogyanya pelaku usaha air minum dalam kemasan Merek Aqua hendaknya memperhatikan tentang Trust dan loyalitas konsumen yang harus tetap dipertahankan atau bahkan ditingkatkan. Misalnya produsen air minum dalam kemasan Merek Aqua merancang iklan dengan menggunakan tenaga ahli di bidang kesehatan yang sudah dikenal baik oleh masyarakat luas sebagai model iklan. 
- Variabel Perceived CSR adalah variabel moderasi antara pengaruh Trust terhadap loyalityas. Hasil penelitian membuktikan bahwa peran tersebut positif dan kuat. Oleh karena itu, produsen air minum dalam kemasan Merek Aqua apabila hendak memprioritaskan pilihan strategi Perceived CSR, guna meningkatkan Loyalitas dan repurchase intention. Misalnya produsen air minum dalam kemasan Merek Aqua terus menerus membangun citra positif dengan cara turut serta terlibat aktif dalam penyediaan air bersih di daerah-daerah minus di Indonesia dan aktivitas ini digunakan sebagai salah satu versi dalam program iklan.

\section{IMPLIKASI TEORITIS}

Implikasi teoritis dari hasil penelitian ini adalah bahwa untuk penelitian yang akan datang hendaknya menggali lebih jauh anteseden repurchase intention, seperti misalnya program-program loyalitas.

\section{KETERBATASAN PENELITIAN}

Penelitian ini tentu saja memiliki keterbatasan. Keterbatasan tersebut adalah variabel-variabel dependen hanya diukur dengan anteseden tunggal. Sementara, berdasarkan kajian teoritis, sesungguhnya variabel-variabel dependen tersebut dapat diukur dengan multi anteseden. 


\section{DAFTAR PUSTAKA}

Arcana, N. 1996. Pengantar Statistik II untuk Ekonomi Bagian Inferensial. Surabaya: Fakultas Ekonomi Universitas Katolik Widya Mandala.

Azjen, I. 1991. The Theory of Planned Behavior, Organizational Behavior and Human Decision Precesses. Volume 50, pp. 179-211.

Babbie, Earl. 1986. The Practice of Social Research. Fourth Edition. United State of America: Wadsworth Inc.

Budimanta, Arif. 2004. Corporate Social Responsibility: Jawaban Bagi Model Pembangunan indonesia Masa Kini. Jakarta: ICSD.

Doney, P. M. dan J. P. Cannon. 1997. "An Examination of the Nature of Trust in Buyer-Seller Relationships”. Journal of Marketing. Nomor 61, pp 35-51.

Fishbein, M. 1967. "A Behavior Theory Approach to the Relations between Beliefs about an Object and Attitude toward the Object, dalam Fishbein, M. (Ed.)”. Readings in Attitude Theory and Measurement, New York, Wiley, pp 389-400.

Gefen, David dan Detmar W. Straub. 2004. "Consumer trust in B2C e-Commerce and the importance of social presence: experiments in e-Products and e-Services”. The International Journal of Management Science, Omega 32, pp 407-424.

Geyskens, I., J-B E. M. Steenkamp, L. K. Scheer dan N. Kumar. 1996. "The Effect of Trust and Interdependence on relationship commitment: A Trans-Atlantic Study”. International Journal of research in Marketing, Nomor 13, pp 303-317.

Ghozali, Imam. 2008. Structural Equation Modeling PLS. Edisi 2, Semarang: Badan Penerbit Universitas Diponegoro.

Griffin, R.W. 1995, Management. Houghton M.C., Boston.

Hosmer, L. T. 1995. “Trust: the Connecting Link between Organizational Theory and Philosophical Ethics”. AMR. Volume 20, Nomor 2, pp 379-403.

Huang, Shan-Yan, ci-Rong Li dan Chen-Ju Lin. 2007. “A Literature Review of Online Trust in Business to Consumer E-Commerce Transactions, 2001-2006”, Information Systems, Volume VIII, Nomor 2, pp 63-69.

Husted, B. 1998. “The Ethical Limits of Trust in Business Relations”. Business Ethics Quarterly, Volume 8, Nomor 2, pp. 233-248.

Jarvenpaa, Sikka L., Noam Tractinsky dan Lauri Saarinen. 1999. “Consumer Trust in an Internet Store: A Cross-Cultural Validation”. Journal of Computer- Mediated Communication, Volume 5, Nomor 2.

Johnson-George, C., dan W. C. Swap. 1982. Meausrement of Specific Interpersonal Trust: Construction and Validation of a Scale to Assess Trust in a Specific Other, Volume 43, Nomor 6, pp. 1306-17.

Kotler, Philip. 1994. Marketing Management: Analysis, Planning, Implementation and Control, Engllewood Cliffs, New Jork: Prentice Hall, Inc.

Lewis, J. D., dan A. Weigert. 1985. “Trust as a Social Reality”. Social Forces, Volume 63, Nomor 4, pp 967-985.

Lumsden, J. dan Mackay L. 2006. “How Does Personality Affect Trust in B2C e-Commerce?”. The Proceedings of the $8^{\text {th }}$ International Conference on Electronic Commerce (ICEC'2006). Canada: National Research Council of Canada.

Malhotra, K Naresh. 1993. Marketing Research: An Apllied Orientation, New Jersey: Englewood Cliffs.

Mayer, R. J., J. H. Davis dan F. D. Schoorman. 1995. “An Integrative Model of Organizational Trust”. Academy of Management Review. Nomor 20, pp 709-734.

McKnight, D.H, L.L. Cummings, N.L. Chervany. 1998. "Initial Trust Formation in New Organizational Realtionships”. Academic Management Review. Volume 23, Nomor 3, pp 473 - 490.

Moorman, C., G. Zaltman, dan R. Deshpande. 1992. "Relationship between Providers and Users of Market Research: The Dynamics of Trust within and between Organizations”. Journal of Marketing Research. Volume 29, pp. 314-328. 
Nazir, Mohammad. 1998. Metode Penelitian, Cetakan 3, Jakarta: Ghalia Indonesia.

Quelch, J. A. dan L. R. Klein. 1996. "The Internet and International Marketing”. Sloan Management Review, Volume 3, Nomor 37, pp 60-75.

Rempel, J. K., J. G. Holmes, dan M. P. Janna. 1985. “Trust in Close Relationships” Journal of Pers Social Psychology. Volume 49, Nomor 1, pp. 95-112.

Roesseau, D. M., S. B. Sitkin, R. S. Burt, dan C. Camerer. 1998. "Not so Different after all: a CrossDiscipline View of Trust”. AMR. Volume 23, Nomor 3, pp 393-404.

Solimun. 2008. Memahami Metode Kuantitatif Mutakhir: Structural Equation Modeling \& Partial Least Square. Malang: Program Studi Statistika FMIPA Universitas Brawijaya.

Thibaut, J. W., H. H. Kelley. 1959. The Social Psychology of Groups. New York: Wiley.

Yuen, Kwok Tak. 2007. The Effect of Customer Trust on Customer Loyalty and Repurchase Intention: The Moderating Influence of Perceived CS., Hong Kong : Baptist University. 